\title{
The effect of military clothing on gunshot wounding patterns in gelatine
}

\author{
Tom Stevenson ${ }^{1,2}$ (1) Debra J. Carr ${ }^{1,3} \cdot$ Sarah A. Stapley $^{4}$
}

Received: 29 August 2018 / Accepted: 13 November 2018 / Published online: 28 November 2018

(C) The Author(s) 2018

\begin{abstract}
With no two gunshot wounds (GSW) being the same, novel research into wound ballistics is challenging. It is evident that the majority of previous wound ballistic research has been conducted without the presence of clothing. Whilst the effect of clothing on wound contamination has been explored, there is a paucity of literature examining the effect of clothing on GSW patterns. The aim of this study was to test the effect of Multi-Terrain Pattern (MTP) UK military clothing on GSW patterns within calibrated blocks of $10 \%$ by mass gelatine, using two types of ammunition commonly used in recent conflicts- $7.62 \times 39 \mathrm{~mm}$ and $5.45 \times$ $39 \mathrm{~mm}$. In total, 36 blocks were shot, 18 by each projectile type, further divided into 6 with no clothing layers $\left(\mathrm{C}_{\text {nil }}\right), 6$ with a single clothing layer $\left(\mathrm{C}_{\min }\right)$ and 6 with maximum clothing layers $\left(\mathrm{C}_{\max }\right)$ worn on active duty. Blocks were analysed with highspeed video and dissection to capture measurements of damage, and results compared using analysis of variance (ANOVA). Results showed significantly different damage measurements within blocks with $\mathrm{C}_{\max }$ for both ammunition types compared to the other clothing states. This may result in GSWs that require more extensive surgical management, inviting further study.
\end{abstract}

Keywords Gunshot $\cdot$ Wounding $\cdot$ Clothing $\cdot$ Gelatine $\cdot$ Military $\cdot$ AK47 $\cdot$ AK74

\section{Introduction}

During the recent Iraq and Afghanistan wars (2003-2014), the UK military suffered 723 gunshot wound (GSW) casualties with 177 fatalities and 546 survivors leading to a substantial clinical burden [1]. Historical review has demonstrated that clinical lessons learned from previous conflicts are often lost, leading to potentially avoidable higher morbidity amongst casualties $[2,3]$. It is therefore paramount that studies are

Electronic supplementary material The online version of this article (https://doi.org/10.1007/s00414-018-1972-8) contains supplementary material, which is available to authorized users.

Tom Stevenson

t.stevenson@ cranfield.ac.uk

1 Impact and Armour Group, Centre for Defence Engineering, Defence Academy of the United Kingdom, Cranfield University, Shrivenham SN6 8LA, UK

2 Cranfield Forensic Institute, Defence Academy of the United Kingdom, Cranfield University, Shrivenham SN6 8LA, UK

3 Present address: Defence and Security Accelerator, Porton Down, Salisbury SP4 0JQ, UK

4 Royal Centre for Defence Medicine, ICT Building, Research Park, St Vincent Drive, Birmingham B15 2SQ, UK undertaken using appropriate methods to continually test existing theory and research conducted over the last century, and help develop novel strategies to further understand wound ballistics. This may improve patient outcomes [4], and ultimately retain corporate knowledge gained previously and pass it on to the next generation of clinicians.

The majority of existing GSW research has been conducted on naked animals or cadavers or bare tissue simulants [e.g. 5-16]. Whilst the effects of clothing on GSW have been examined with respect to contamination [e.g. 17-21], there remains a paucity of literature examining the effect of clothing on the wounding patterns; exceptions include separate works by Kieser, Carr, Mabbott and Mahoney [22-25].

Gelatine has been used for wound ballistic research since the early twentieth century, with different concentrations and configurations depending on the aims of the respective studies [26-34]. Research conducted at the Letterman Institute in the USA re-validated the use of gelatine as comparable to live swine thigh muscle tissue with regard to its response to ballistic testing. This can offer a useful way to visualise GSW profiles from different ammunition types [35-37]. Studies from the last 5 years have examined the difference in gelatine concentrations to determine positive and negative attributes for certain uses within wound ballistic research [24, 38, 39]. The use of gelatine in wound ballistic research has also recently been summarised and highlights the difficulty in accurately 
reproducing wounding patterns despite controlling as many variables as possible [4]. With clinicians often stating that no two GSWs are ever the same [40], such modelling poses a real challenge to the researcher in order to achieve their aim. As well as gelatine, other media used in ballistic modelling include ballistic soap, cadaveric animal and human tissue, live animal tissue and other synthetic tissue simulants, all of which have been subject of recent review [41].

It helps to consider wounding patterns that occur within gelatine blocks in several different stages which are explored in greater detail within Kneubehl's comprehensive text "Wound Ballistics" [42] and are summarised as follows:

- Temporary cavity: The temporary cavity is formed following transfer of kinetic energy (KE) from the projectile to the gelatine. The KE causes the gelatine to radially accelerate away from the projectile, generating negative pressure, drawing air in from the entrance (and/or exit) wound and forming the temporary cavity. The size of the temporary cavity can vary along the wound track and is determined by the amount of KE being transferred, which is in turn determined by the contact surface area of the projectile. Should the projectile yaw, expand and/or fragment, its contact surface area with the target is increased at that point, causing an increase in drag coefficient resulting in more rapid deceleration, and leads to greater delivery of $\mathrm{KE}$ and thus greater temporary cavitation. The temporary cavity, by the physical properties associated with its formation, is multiple times larger than the permanent cavity left behind.

- Permanent cavity: This consists of the track formed by the projectile crushing and cutting its way through the gelatine, and the damage caused by the formation and collapse of the temporary cavity. When a projectile of a certain type (for example military projectiles, such as $7.62 \times 39 \mathrm{~mm}$ ) strikes a target nose on, an initial narrow wound channel (i.e. the neck length) is created whilst the projectile is still travelling symmetrically (and is arguably of the greatest surgical relevance as marginal to no surgical debridement of tissues is required [14, 43]). There is little damage seen as the projectile's contact surface area with the gelatine is at its minimum. With a longer neck length, the projectile may go on to exit the target before yawing, and as such takes the majority of KE with it, leaving a potentially smaller and simpler wound profile behind-again, clinically, this is important and will be revisited within the discussion section of this paper. It should be noted that other ammunition types, such as expanding projectiles, may have little to no neck length at all with extensive cavitation seen. Other projectile types, such as ball bearings, are of a uniform spherical shape so will not yaw and also do not deform in shape and may only leave a narrow track following minimal temporary cavitation. Knowledge of these properties helps identify wound patterns attributable to those projectile types.

Understanding the wounding pattern helps facilitate calculation of the area or volume of gelatine damage seen. With respect to what measurements are relevant, this is variable and is determined by the aim of the study. Examples include measuring the depth of penetration (DoP) of projectiles into the gelatine block, the dimensions of the temporary cavity using high-speed video (HSV), the dimensions of the permanent cavity, the distance from entry to which the projectile yaws $90^{\circ}$ and imaging of wound tracks using medical imaging modalities [4, 22, 24, 25, 36, 44-48].

The types of ammunition used in ballistic modelling are dependent on what the subject for study demands. Typically for modelling directed at the use of military grade firearms, high-velocity rifle ammunition is used, e.g. $7.62 \times 39 \mathrm{~mm}$, 7.62 NATO $(7.62 \times 51 \mathrm{~mm}), 5.45 \times 39 \mathrm{~mm}$ and 5.56 NATO $(5.56 \times 45 \mathrm{~mm})$. This list is by no means exhaustive; there are numerous studies examining different projectile types, such as steel ball bearings $[24,49]$. With physical, mechanical and ballistic properties of ammunition varying widely but rarely being discussed within the literature, it is preferential to use a single quarantined batch of required ammunition types and, if necessary, identify composition and microhardness [4].

The ballistic protective performance of winter issue military clothing has been reported; however, this examined the failure of the clothing rather than any wounding patterns seen as a result of ballistic impact [50]. A study of rifle ammunition effects on tissues considered anaesthetized pigs clothed in Finnish military uniforms however made no comment on the effect of the presence of the clothing on the wounding patterns [51].

More recently published was a study that showed the presence of a layer of denim on a model of a deer femur embedded in $20 \%$ (by mass) gelatine led to an increase in the risk of indirect femoral fracture when shot by 5.56 NATO ammunition [22], followed by an increasing interest in examining clothing effects on wounding in ballistic research [e.g. 4, 20, $21,23,44,45]$. Published research has demonstrated that intermediate layers (clothing or other personal protective equipment) can affect damage sustained by a gelatine block during ballistic testing [e.g. 22, 23, 25, 44].

Whilst it can be acknowledged that previous research on naked tissue and tissue simulants has been conducted, it is evident that professional troops going into active conflict in the modern era will be appropriately clothed. With respect to UK service personnel, that clothing is typically in the form of standard issue Multi-Terrain Pattern (MTP) clothing, with different layers worn depending on the climate and the nature of the operations being conducted. The effect of military clothing on wounding patterns does not appear to have previously been examined. 
The aim of the current study was to characterise the effect of military clothing on GSW patterns in blocks of $10 \%$ by mass-calibrated gelatine using $7.62 \times 39 \mathrm{~mm}$ and $5.45 \times$ $39 \mathrm{~mm}$ ammunition, whilst considering the clinical relevance of the results.

\section{Materials and methods}

Ethical approval for this work was granted via Cranfield University Research Ethics System (CURES/3579/2017).

\section{Materials}

Thirty-six blocks of $10 \%$ (by mass) gelatine were made in batches of six from type 3 photographic grade gelatine (GELITA® AG, Uferstraße 7, 69412, Eberbach, Germany; bloom strength 263). Moulding tins had inside dimensions of $250 \times 250 \times 500 \mathrm{~mm}$, with a $1^{\circ}$ taper to facilitate set gelatine removal [44]. The blocks were conditioned at $4{ }^{\circ} \mathrm{C}$ for $24 \mathrm{~h}$ after setting.

The MTP clothing selected for investigation was divided into different states to represent the minimal and maximal layers worn globally by UK personnel on combat and frontline duties. Firstly, bare blocks of gelatine or a zero clothing state $\left(\mathrm{C}_{\text {nil }}\right)$ was used for a control. The minimal clothing state $\left(\mathrm{C}_{\min }\right)$ was represented by a single clothing layer taken from MTP trousers ${ }^{1}(n=6)$ (Fig. 1). Finally, the maximal clothing state $\left(\mathrm{C}_{\max }\right)$ involved several layers of clothing including a base layer standard issue $\mathrm{t}-\operatorname{shirt}^{2}(n=6)$, upper arm sleeve pocket of Under Body Armour Combat Shirt (UBACS) ${ }^{3}$ $(n=6)$, the upper arm sleeve pocket of an MTP smock jacket ${ }^{4}$ $(n=6)$ and finally a brassard (upper arm protection). The brassard consisted of a fragment protective filler ${ }^{5}$ manufactured from a para-aramid fabric, sealed in a light- and water-resistant cover. This was inserted into an outer carrier ${ }^{6}$ which attaches to the body armour torso as part of the OSPREY body armour system ( $n=12$ for both items) (Fig. 1) [52]. All clothing, excluding the brassards, was laundered (following procedure 8A of British Standard EN ISO 6330: 2001) by washing six times before drying informed by the care label provided in the garment and to ensure the removal of any finishing treatments and dimensional stability of the fabric [53]. ${ }^{7}$

\footnotetext{
$\overline{1}$ Trouser, combat, warm weather MTP_-NATO stock number (NSN): 841599-317-8313

${ }^{2}$ T-shirt, combat, anti-static, light olive-NSN: 8415-99-813-3258

${ }^{3}$ Shirt, UBACS, MTP-NSN: 8415-99-317-8402

${ }^{4}$ Smock, combat, windproof, MTP-NSN: 8415-99-317-8386

${ }^{5}$ Filler Osprey Mk 2-NSN: 8470-99-480-8055

${ }^{6}$ Osprey MKIVA (MTP) cover brassard-NSN: 8470-99-684-4613-4

${ }^{7}$ BEKO washing machine (model number WM84125W) used on a cotton cycle lasting $79 \mathrm{~min}$ per cycle with a water temperature of $40{ }^{\circ} \mathrm{C}$; BEKO tumble dryer (model number DSV64W) used on a 60-min cycle at the standard factory set temperature (not listed).
}

Fabric samples of individual clothing layers were analysed $(n=5)$ in order to characterise their physical properties. Mass per unit area and thickness of the samples were measured [54, 55], using Oxford A2204 scales to measure mass and a Mitutoyo C1012MB thickness gauge to measure thickness of the MTP trouser single layer for $\mathrm{C}_{\min }$, and the individual layers of the t-shirt, UBACS and smock as part of $\mathrm{C}_{\max }$. The brassard and all combined layers for $\mathrm{C}_{\max }$ were measured using Mettler PE16 scales for mass and a Shirley Thickness Gauge (Shirley Developments Ltd., 87,137) for thickness.

In recent conflicts that UK Armed Personnel have participated in, a wide range of weapons systems were used. Two common weapons systems available in Iraq and Afghanistan (2003-2014) that were used against UK Armed Forces were the AK47 and the AK74 [56, 57]. The ammunition used with these weapons systems is $7.62 \times 39 \mathrm{~mm}$ and $5.45 \times 39 \mathrm{~mm}$, respectively. Therefore, these two types of ammunition were used in the current study. To help control the variability in ammunition batch production, batches of ammunition were quarantined for this study: $7.62 \times 39 \mathrm{~mm}(7.62 \times 39 \mathrm{~mm}$ Wolf Hunting Cartridges; lead core, 122 grain full metal jacket, lot number F-570, made in Russia, 2006) and $5.45 \times$ $39 \mathrm{~mm}(5.45 \times 39 \mathrm{~mm}$; mild steel core, 53 grain full metal jacket, lot number 539-04, made in Russia, 2004) (Fig. 2). Hardness was determined by sectioning and encapsulating projectiles in epoxy resin $(n=3)$, using a Struers Rotopol 15 to polish the sample projectiles, and an Indentec Highwood microscope with diamond tipped load point to measure hardness. Elemental composition was determined using a Hitachi SU3500 scanning electron microscope with EDAX analysis and TEAM software.

\section{Methods}

Fabric samples for $\mathrm{C}_{\min }$ were cut from laundered MTP trousers $(250 \times 250 \mathrm{~mm})$ and pinned to the front face of the gelatine blocks (Fig. 3). Fabric samples for $\mathrm{C}_{\max }$ were measured and cut in relation to the upper sleeve pocket size on the UBACS and smocks $(200 \times 150 \mathrm{~mm})$, and placed in layers with the t-shirt layer innermost, then UBACS, smock and finally with the brassard then placed over the top of the other layers (Fig. 3).

An indoor small arms range was used to fire projectiles from a number 3 proof housing, where the end of the barrel was situated at $10 \mathrm{~m}$ from the target. The gelatine was calibrated by firing a $5.5 \mathrm{~mm}$ ball bearing into each block; DoP was measured and compared to previously published studies to ensure validity of the blocks used in this series of experiments $[25,38,58]$. Each block was then shot once with the test projectiles. Eighteen blocks were shot with $7.62 \mathrm{~mm}$ projectiles and the remaining 18 blocks were shot with $5.45 \mathrm{~mm}$ projectiles. Six blocks for each ammunition type had either $\mathrm{C}_{\text {nil }}, \mathrm{C}_{\min }$ or $\mathrm{C}_{\max }$ added to the impact face. 
Fig. 1 Examples of MTP clothing used. clockwise from top left MTP trousers. top right $\mathrm{T}$ shirt, UBACS, smock and brassard as worn by service personnel. bottom (i) T-shirt, (ii) UBACS, (iii) smock and (iv) brassard layers prepared for testing

Fig. 2 Mounted sections of $7.62 \mathrm{~mm}$ (left) and $5.45 \mathrm{~mm}$ (right) projectiles
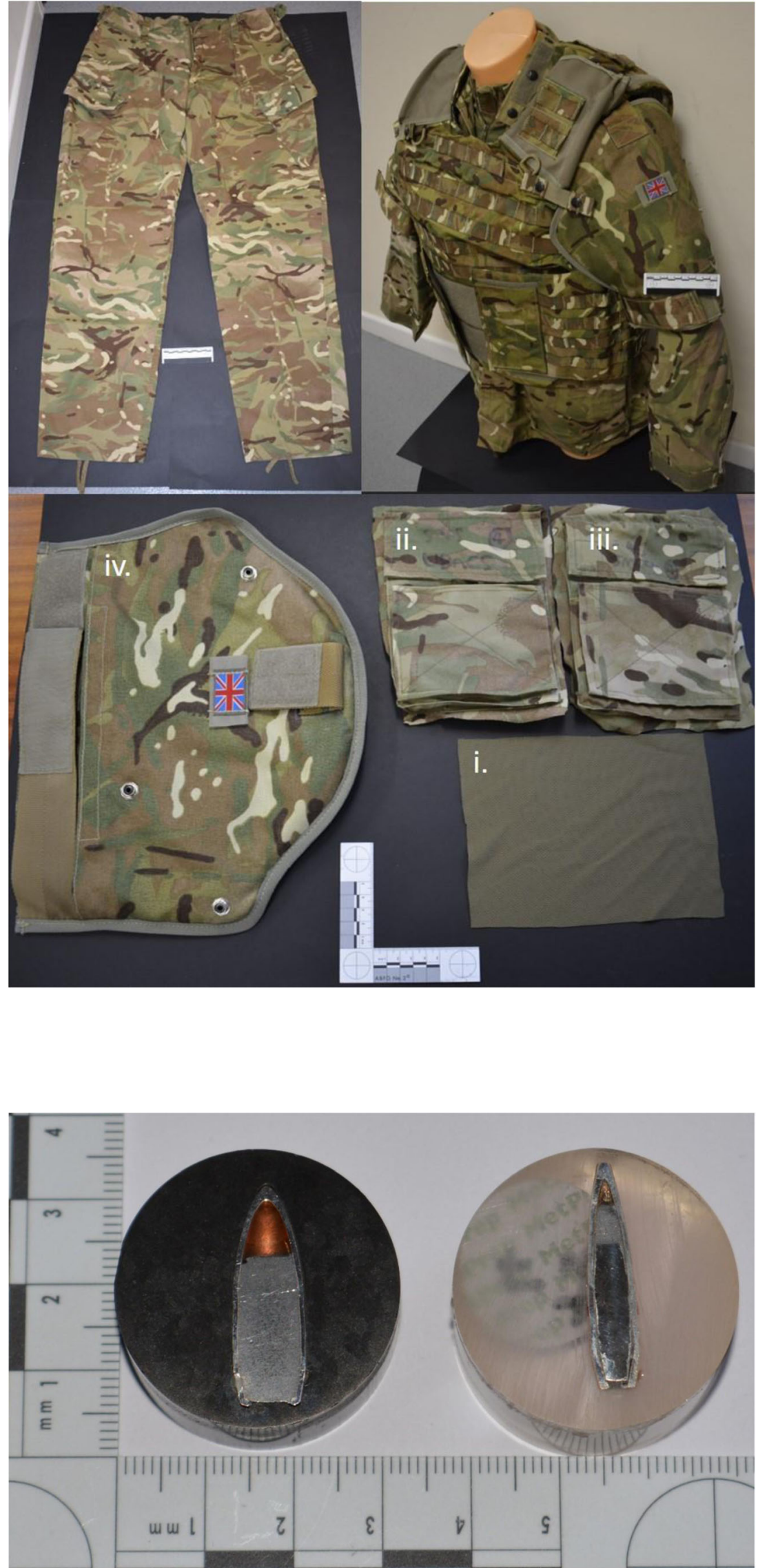
Fig. 3 clockwise from top left $\mathrm{C}_{\mathrm{nil}}$ oblique view, $\mathrm{C}_{\min }$ oblique view, $\mathrm{C}_{\max }$ side view, $\mathrm{C}_{\max }$ oblique view

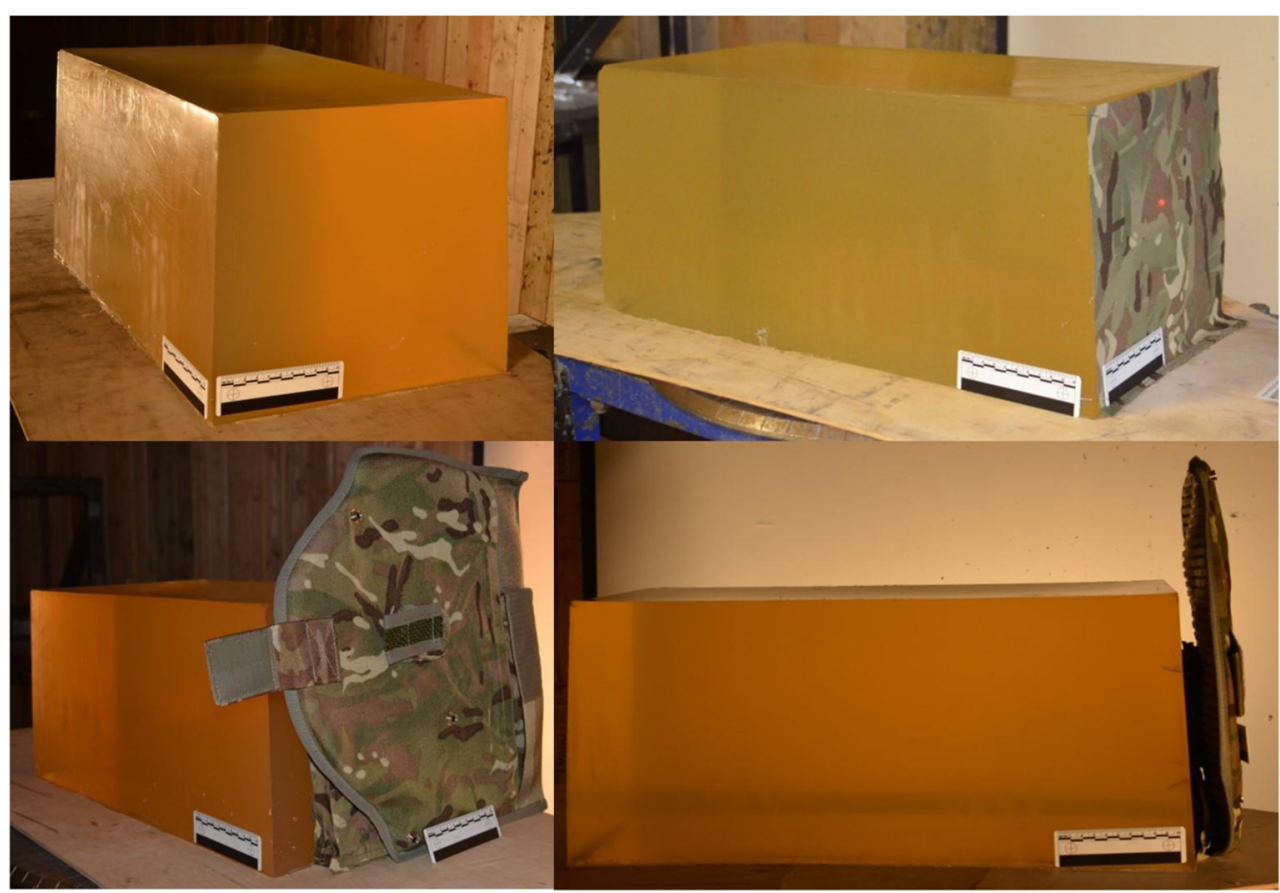

The impact velocity for each projectile was measured using Doppler radar (Weibel W700). HSV using a Phantom V1212 video camera (frames per second $=37,000$, shutter speed $=5 \mu \mathrm{s}$, resolution $=512 \times 384$ ) allowed visualisation of the wounding pattern and to record the formation of the temporary cavity. Measureable parameters were taken from the HSV of this phenomenon using Phantom Software (Visions Research, Phantom Camera Control Application 2.6). These parameters included maximum height of the temporary cavity (H1) and distance to the maximum height of the temporary cavity (D1), where the latter corresponded to the point where the projectile was at maximum yaw of $90^{\circ}$ [36] (e.g. Fig. 4a). Temperature of the gelatine blocks was recorded after shooting using a calibrated digital thermometer. Black food colouring was poured in via entrance wounds of the gelatine blocks to visually highlight wounds. Gelatine blocks were then dissected and any fragmentation of the projectiles noted and recovered. The damage to the gelatine block was photographed using a Canon D5100 Digital SLR camera (S/N 6773411). The parameters of damage measured were maximum height of the permanent cavity (H2), distance to maximum height of the permanent cavity (D2) and neck length (NL) (e.g. Fig. 4b).

The International Business Machine Corporation's Statistical Package for Social Services version 24 (IBM SPSS Statistics v24) analysis of variance (ANOVA) was used to determine the effect of the different clothing states ${ }^{8}$ on $\mathrm{H} 1$, D1, H2, D2 and NL. The two ammunition types were

\footnotetext{
$\overline{{ }^{8} \text { The effects of }} C_{\min }$ on GSW patterns were presented as a poster at the 30th International Symposium on Ballistics [45].
}

considered together, and homogeneity of variance and normality of data were confirmed with a significance level of 0.05 applied. Significant differences due to ammunition type and/or clothing condition were identified using Tukey's honest significant difference (HSD) test. Main effects and significant interactions only are discussed in the "Results" section.

\section{Results}

Calibration of the gelatine blocks using 5.5-mm-diameter ball bearings (mean impact velocity of $725 \mathrm{~m} / \mathrm{s}, \mathrm{SD}=26 \mathrm{~m} / \mathrm{s}$; mean $\mathrm{DoP}=361 \mathrm{~mm}, \mathrm{SD}=11 \mathrm{~mm}$ ) was similar to previously collected data giving confidence in the consistency of the blocks (Fig. 5). Mean impact velocity for the $7.62-\mathrm{mm}$ projectiles was $648 \mathrm{~m} / \mathrm{s}(\mathrm{SD}=8 \mathrm{~m} / \mathrm{s})$ and for the $5.45-\mathrm{mm}$ projectiles was $883 \mathrm{~m} / \mathrm{s}(\mathrm{SD}=14 \mathrm{~m} / \mathrm{s})$. Mean temperature of the gelatine blocks after testing was $6.8^{\circ} \mathrm{C}\left(\mathrm{SD}=1.6^{\circ} \mathrm{C}\right)$.

Ammunition characteristics are given in Table 1. As expected, both projectiles were jacketed in steel with copper washes and the lead core of the $7.62 \mathrm{~mm}$ projectile was softer than the steel core of the $5.45 \mathrm{~mm}$ projectile which had a soft lead tip.

Mass per unit area and thickness for $\mathrm{C}_{\min }$ and $\mathrm{C}_{\max }$ are given in Table 2. The single trouser layer used for $\mathrm{C}_{\min }$ was thinner and lighter than the combined layers used for $\mathrm{C}_{\max }$ as would be expected. The $\mathrm{C}_{\max }$ thickness and mass per unit area was calculated using all layers together, as would be worn in reality.

Seventeen of the $7.62 \mathrm{~mm}$ projectiles and 10 of the $5.45 \mathrm{~mm}$ projectiles exited the blocks across all clothing 
Temporary cavity measurements

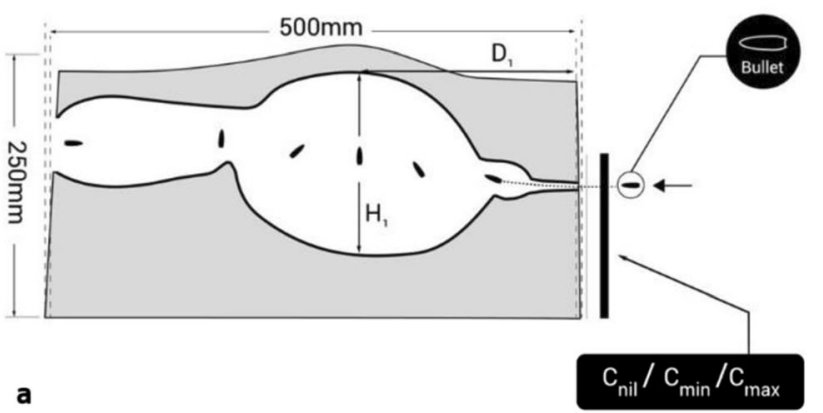

Permanent cavity measurements

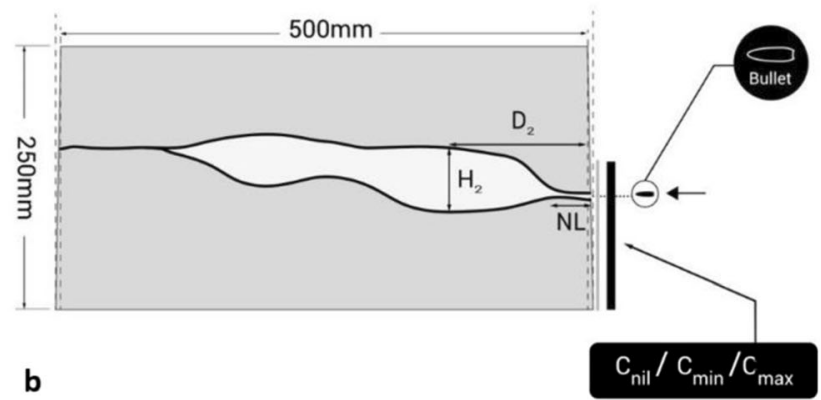

Fig. 4 a Temporary cavity measurement schematic. b Permanent cavity measurement schematic

conditions. For the $7.62 \mathrm{~mm}$ projectiles, all exits were via the rear face. For the $5.45 \mathrm{~mm}$ projectiles, one of the projectiles exiting exited via the rear face, four via the right face (as viewed from the impact face) and five exited via the top face. For projectiles that were retained, the DoP was measured: for the one $7.62 \mathrm{~mm}$ projectile retained, the DoP was $484 \mathrm{~mm}$; for the eight $5.45 \mathrm{~mm}$ projectiles retained, the mean DoP was $423 \mathrm{~mm}(\mathrm{SD}=14 \mathrm{~mm})$, though it was noted from the HSV that all those retained $5.45 \mathrm{~mm}$ projectiles except for one would have exited via the bottom face but instead were retained due to ricochet off the table the block was mounted on. The retained $7.62 \mathrm{~mm}$ projectile was in a gelatine block with $\mathrm{C}_{\text {nil }}$, and the one truly retained $5.45 \mathrm{~mm}$ projectile (which did not ricochet of the base table) was in a block with $\mathrm{C}_{\max }$; therefore, the clothing state was unlikely to have influenced the rate of projectile retention.

Seventeen of the $7.62 \mathrm{~mm}$ projectiles fragmented; $94 \%$ of those fragments were retained within the blocks and four of the 17 shots that fragmented had more than one fragment, with a maximum of three fragments seen (Fig. 6). Mass of fragments varied from 0.04 to $0.61 \mathrm{~g}$ (mean $=0.30 \mathrm{~g}, \mathrm{SD}=$ $0.16 \mathrm{~g}$ ). The difference seen in the number of projectiles that fragmented or the number of fragments seen amongst blocks with or without clothing layers was either non-existent or too small for statistical comparison. The mean DoP of the fragments was $350 \mathrm{~mm}(\mathrm{SD}=97 \mathrm{~mm})$. None of the $5.45 \mathrm{~mm}$ projectiles fragmented. This data suggests that the clothing state did not influence the fragmentation of the projectiles, and that this was more likely due to the composition and construction of each ammunition type and the forces applied to the projectile during the interaction with the target.

The dimensions collected for the damage caused by the temporary and permanent cavities to the gelatine blocks are summarised in Table 3.

When considering the effect of clothing state on data variability from Table 3 for each ammunition type, no clear trends were observed except for the following:

- $7.62 \mathrm{~mm}$ - increasing variability in NL with increasing clothing state and decreasing variability in $\mathrm{H} 2$ with increasing clothing state

- $5.45 \mathrm{~mm}$ - increasing variability in H2 with increasing clothing state and decreasing variability in D1, H1 and D2 with increasing clothing state.
Fig. $510 \%$ gelatine $\left(4{ }^{\circ} \mathrm{C}\right)$ calibration data (Stevenson 2018 current study, compared to historical data $[44,59])$

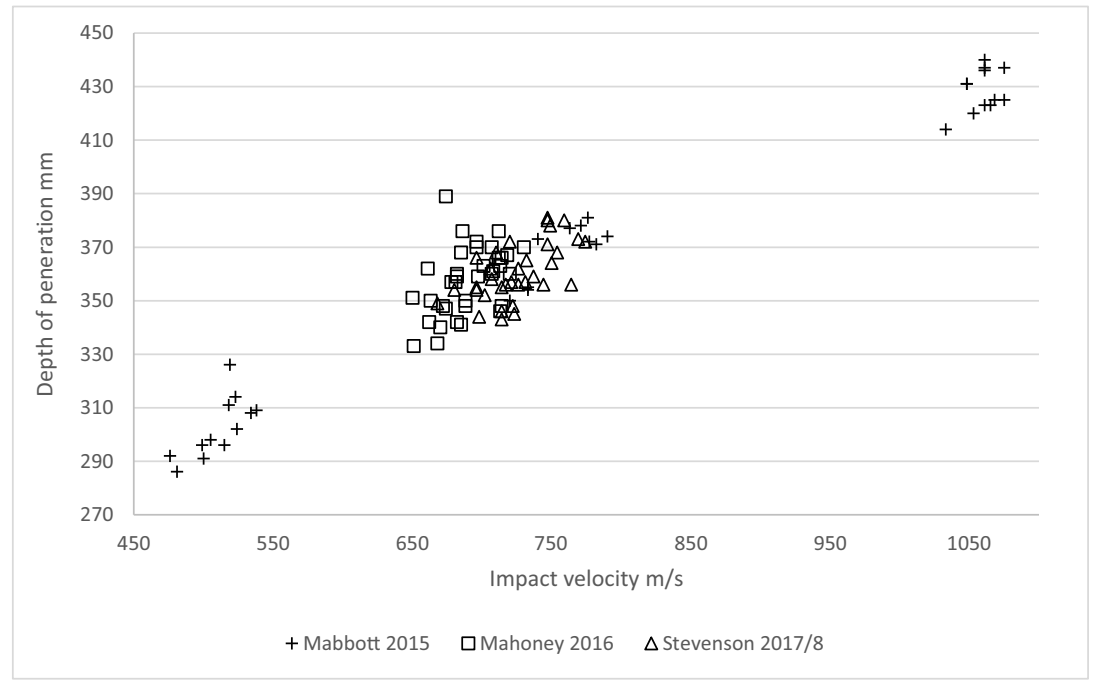


Table 1 Characteristics for $7.62 \times 39 \mathrm{~mm}$ and $5.45 \times 39 \mathrm{~mm}$ ammunition

\begin{tabular}{|c|c|c|c|c|}
\hline \multicolumn{2}{|c|}{ Projectile type } & \multirow{2}{*}{$\begin{array}{l}\text { Core hardness }(\mathrm{Hv}) \\
7.39(n=3)\end{array}$} & \multirow{2}{*}{$\begin{array}{l}\text { Jacket hardness (Hv) } \\
184.57(n=5)\end{array}$} & \multirow{2}{*}{$\begin{array}{l}\text { Tip hardness (Hv) } \\
\text { N/A }\end{array}$} \\
\hline $7.62 \mathrm{~mm}$ & Mean & & & \\
\hline & SD & 0.86 & 9.91 & N/A \\
\hline & Composition & Lead, antimony & Steel (with internal/external copper wash) & $\mathrm{N} / \mathrm{A}$ \\
\hline \multirow[t]{3}{*}{$5.45 \mathrm{~mm}$} & Mean & $820.90(n=3)$ & $188.90(n=5)$ & $4.58(n=2)$ \\
\hline & $\mathrm{SD}$ & 15.85 & 15.41 & 1.05 \\
\hline & Composition & Steel & Steel (with internal/external copper wash) & Lead \\
\hline
\end{tabular}

ANOVA results are given in Table 4 below; data subgroups identified by Tukey's HSD are also included.

In all measurements apart from $\mathrm{H} 2$ it was demonstrated that the clothing state of $\mathrm{C}_{\max }$ led to significantly different measurements when compared to $\mathrm{C}_{\text {nil. }}$. In the cases of NL and D1 measurements, $\mathrm{C}_{\max }$ also led to significantly different measurements when compared to $\mathrm{C}_{\min }$.

\section{Discussion}

The clinical effects of a GSW will be dictated by both the ammunition effects and clothing effects together. When compared to an anatomical overlay (Fig. 7), a projectile which might have otherwise passed through a limb before yawing significantly would yaw sooner within that limb due to $\mathrm{C}_{\max }$. This would cause temporary cavitation to occur earlier and impart a greater amount of $\mathrm{KE}$ and subject those tissues to greater deformative stress. Crucially, the resultant effect would undoubtedly require an increased level of surgical intervention, bringing with it the associated risks of carrying out such surgery to the patient.

Interestingly, the effect of the ammunition on the temporary cavity varied with clothing state. That the temporary cavity height was smaller where $5.45 \mathrm{~mm}$ projectiles are used with $\mathrm{C}_{\max }$ does not matter, because the damage still occurred earlier within the wound tract and was still greater than that seen within the neck length which exists at the same position in blocks with $\mathrm{C}_{\min }$ and $\mathrm{C}_{\text {nil }}$ (Fig. 7 and Table 3).

Introducing a layer of any material, such as clothing, between a projectile and its target brings further potential to alter the symmetry of flight of that projectile. The effect of intermediate layers has been reported previously, though not

Table 2 Mass per unit area and thickness for clothing states

\begin{tabular}{llcc}
\hline Clothing state & Mass per unit area $\left(\mathrm{g} / \mathrm{m}^{2}\right)$ & Thickness $(\mathrm{mm})$ \\
\hline $\mathrm{C}_{\min }$ & Mean & 191.14 & 0.43 \\
& $\mathrm{SD}$ & 1.76 & 0.02 \\
$\mathrm{C}_{\max }$ & Mean & 7735.17 & 32.26 \\
& $\mathrm{SD}$ & 86.02 & 0.97 \\
\hline
\end{tabular}

specifically on the effect of military clothing $[22,23,25$, 44]. The presence of military clothing layers could mean an increased chance of the projectile yawing away from its central axis by several degrees within the microseconds following interaction with the material but before striking its target. This would increase the contact surface area of the projectile striking the target and thus lead to higher KE transfer and potentially subject that tissue to greater damage earlier on in the projectile/target interaction. This holds particular relevance with respect to the NL measurements, where the NL region of a body limb wound typically requires less surgical intervention. This translates to the NL being a key measurement of damage; the longer it is, the more likely the projectile has exited before imparting much of its KE and the chance is greater for a wound pattern requiring less clinical intervention.

The fragmentation of projectiles seen was exclusive to $7.62 \mathrm{~mm}$, and most likely occurred due to the composition and construction of those projectiles rather than due to the clothing state. This was supported by the fact that the only $7.62 \mathrm{~mm}$ projectile not to fragment had passed through $\mathrm{C}_{\max }$, and by the fact that none of the $5.45 \mathrm{~mm}$ projectiles fragmented within blocks of all three clothing states. As the fragments were extremely small, the overall damage they contributed within the wounding patterns was negligible.

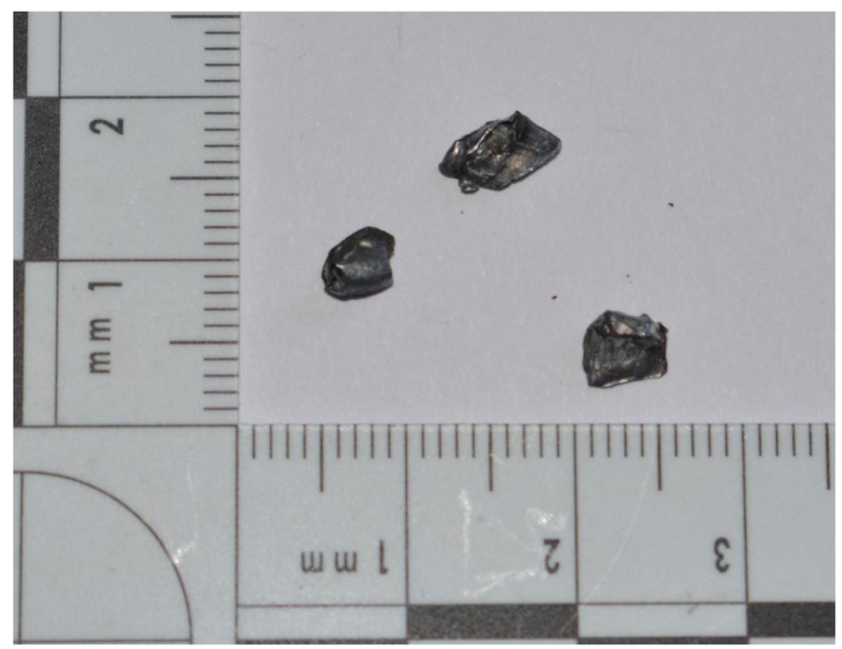

Fig. 6 Typical fragmentation recovered from gelatine shot by a $7.62 \mathrm{~mm}$ projectile 
Table 3 Mean, standard deviation (SD) and coefficient of variation (CV) for dimensions measured

\begin{tabular}{|c|c|c|c|c|c|c|c|c|c|c|c|c|c|c|c|}
\hline \multirow[b]{2}{*}{$\begin{array}{l}\text { Projectile / cloth- } \\
\text { ing state }\end{array}$} & \multicolumn{3}{|l|}{ NL } & \multicolumn{3}{|l|}{ D1 } & \multicolumn{3}{|l|}{ H1 } & \multicolumn{3}{|l|}{ D2 } & \multicolumn{3}{|l|}{$\mathrm{H} 2$} \\
\hline & $\begin{array}{l}\text { Mean } \\
(\mathrm{mm})\end{array}$ & $\begin{array}{l}\text { SD } \\
(\mathrm{mm})\end{array}$ & $\begin{array}{l}\mathrm{CV} \\
(\%)\end{array}$ & $\begin{array}{l}\text { Mean } \\
(\mathrm{mm})\end{array}$ & $\begin{array}{l}\text { SD } \\
(\mathrm{mm})\end{array}$ & $\begin{array}{l}\mathrm{CV} \\
(\%)\end{array}$ & $\begin{array}{l}\text { Mean } \\
(\mathrm{mm})\end{array}$ & $\begin{array}{l}\text { SD } \\
(\mathrm{mm})\end{array}$ & $\begin{array}{l}\mathrm{CV} \\
(\%)\end{array}$ & $\begin{array}{l}\text { Mean } \\
(\mathrm{mm})\end{array}$ & $\begin{array}{l}\text { SD } \\
(\mathrm{mm})\end{array}$ & $\begin{array}{l}\mathrm{CV} \\
(\%)\end{array}$ & $\begin{array}{l}\text { Mean } \\
(\mathrm{mm})\end{array}$ & $\begin{array}{l}\text { SD } \\
(\mathrm{mm})\end{array}$ & $\begin{array}{l}\mathrm{CV} \\
(\%)\end{array}$ \\
\hline $7.62 \mathrm{~mm} / \mathrm{C}_{\text {nil }}$ & 72.5 & 41.6 & 57.3 & 195.3 & 31.0 & 15.9 & 184.7 & 21.7 & 11.7 & 199.7 & 54.5 & 27.3 & 132.7 & 30.5 & 23.0 \\
\hline $7.62 \mathrm{~mm} / \mathrm{C}_{\min }$ & 74.5 & 58.3 & 78.3 & 191.0 & 63.4 & 33.2 & 192.8 & 13.6 & 7.0 & 178.0 & 69.8 & 39.2 & 133.2 & 29.0 & 21.8 \\
\hline $7.62 \mathrm{~mm} / \mathrm{C}_{\max }$ & 26.3 & 22.0 & 83.6 & 153.0 & 30.3 & 19.8 & 204.0 & 28.4 & 13.9 & 135.0 & 38.0 & 28.0 & 122.0 & 17.3 & 14.2 \\
\hline $5.45 \mathrm{~mm} / \mathrm{C}_{\mathrm{nil}}$ & 71.7 & 43.8 & 61.1 & 179.0 & 39.9 & 22.3 & 211.3 & 29.8 & 14.1 & 152.7 & 47.0 & 30.8 & 134.7 & 5.0 & 3.7 \\
\hline $5.45 \mathrm{~mm} / \mathrm{C}_{\min }$ & 51.0 & 12.1 & 23.8 & 182.0 & 18.5 & 10.2 & 181.7 & 8.5 & 4.7 & 163.0 & 44.7 & 27.4 & 126.7 & 7.6 & 6.0 \\
\hline $5.45 \mathrm{~mm} / \mathrm{C}_{\max }$ & 9.7 & 8.2 & 84.5 & 116.0 & 10.0 & 8.7 & 173.0 & 7.5 & 4.3 & 108.0 & 22.1 & 20.5 & 128.0 & 9.4 & 7.3 \\
\hline
\end{tabular}

Clinically, removing such fragments has the potential to cause more harm than benefit so, unless causing direct neurovascular injury, operating clinicians sometimes opt to leave them in situ.

Of qualitative interest was that the visual inspection of the HSV data showed a wounding pattern seen in real time that was grossly peculiar to each ammunition type irrespective of the presence of clothing layers as shown in the animations (Online resources 1 and 2), though this observation in itself was not further quantified or statistically tested beyond the above results.

Microhardness and elemental analysis results suggested that both types of ammunition were manufactured consistently. This was also true of the fabric analysis results with regard to the use of the different layers of MTP for the relevant clothing states. To the knowledge of the authors of this work, the effect of UK military clothing on GSW patterns has not previously been considered within existing literature.

\section{Limitations}

One of the main limitations of this model is that gelatine is a synthetic medium and as such cannot in any way allow comment on tissue viability within such wounds as re-created in this study. As such, a number of assumptions have to be made when considering the clinical relevance of wounding patterns within synthetic modelling. It stands to reason that where maximal temporary cavitation occurs, tissues in a live subject would be exposed to greater stress and potential damage compared to an area in the tissue where temporary cavitation is minimal, i.e., the neck length, though without live tissue testing under the same conditions, it cannot be proven beyond the anecdotal experience of authors whom have seen such injuries within their clinical practice and can provide comment.

Another limitation is clothing type. Though in regular use on day-to-day active service for the UK military, the MTP clothing selected for this testing does not appear to have been previously discussed. This means that there is no way to compare the results of this study directly with other studies at this time, although it does offer a point of comparison for future studies.

The ammunition types chosen also are a limitation where troops can be exposed to a plethora of different ammunition types during conflicts, depending entirely on the enemy logistical infrastructure. Even ammunition of the same type may have different physical properties and characteristics due to being of different batches or manufactured in different countries [4].

Other limitations include the fixed engagement distance and controlled projectile velocities; it is unlikely to expect that GSWs are sustained regularly at muzzle velocity with a projectile flying symmetrically in all combat scenarios. Engagement distances with the enemy will always vary, as will the subsequent velocity and potential asymmetry of the projectile in flight upon striking the target; thus, the behaviour of the ammunition being fired is determined due to the number

Table 4 ANOVA results

\begin{tabular}{|c|c|c|c|c|}
\hline \multirow[t]{2}{*}{ Measurement } & \multicolumn{2}{|c|}{ ANOVA effects ( $F$-statistic, $p$ value) } & \multicolumn{2}{|c|}{ Data subsets found (Tukey's HSD) } \\
\hline & Clothing state & Ammunition type & Group 1 & Group 2 \\
\hline NL & $F_{2,30}=7.39, p \leq 0.01$ & $F_{1,30}=3.10, p=\mathrm{NS}$ & $\mathrm{C}_{\max }$ & $\mathrm{C}_{\min }, \mathrm{C}_{\mathrm{nil}}$ \\
\hline D1 & $F_{2,30}=7.12, p \leq 0.01$ & $F_{1,30}=6.05, p \leq 0.05$ & $\mathrm{C}_{\max }$ & $\mathrm{C}_{\min }, \mathrm{C}_{\mathrm{nil}}$ \\
\hline H1 & $F_{2,30}=4.88, p \leq 0.05$ & $F_{1,30}=6.96, p \leq 0.05$ & $\mathrm{C}_{\max }, \mathrm{C}_{\min }$ & $\mathrm{C}_{\min }, \mathrm{C}_{\mathrm{nil}}$ \\
\hline D2 & $F_{2,30}=4.26, p \leq 0.05$ & $F_{1,30}=6.75, p \leq 0.05$ & $\mathrm{C}_{\max }, \mathrm{C}_{\min }$ & $\mathrm{C}_{\min }, \mathrm{C}_{\text {nil }}$ \\
\hline $\mathrm{H} 2$ & $F_{2,30}=0.74, p=\mathrm{NS}$ & $F_{1,30}=0.26, p=\mathrm{NS}$ & No subgroups identified & \\
\hline
\end{tabular}


Key

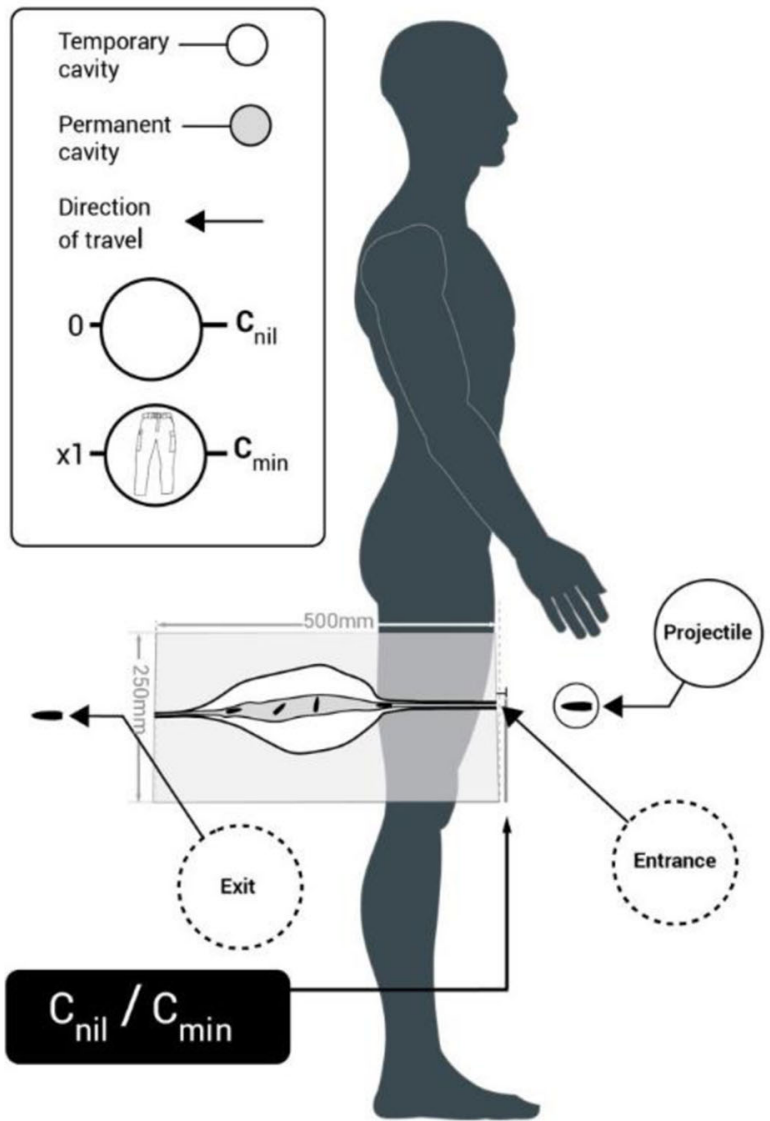

Key
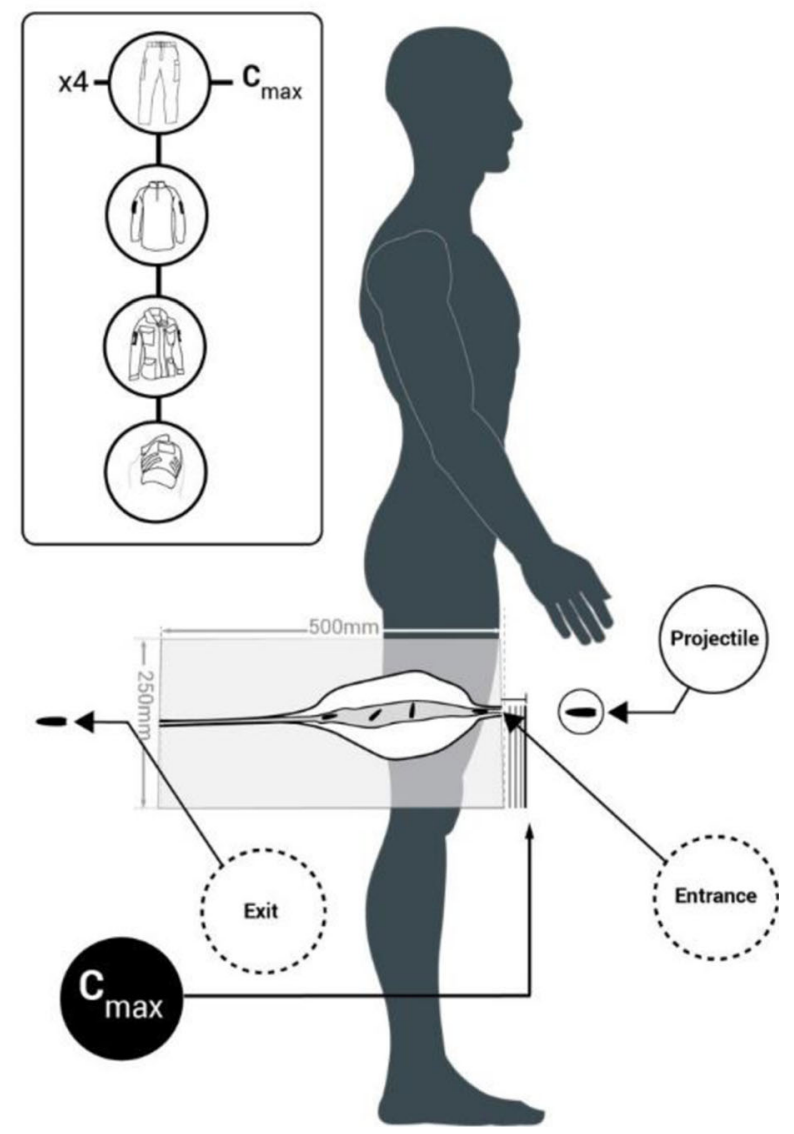

Fig. 7 Anatomical overlay of GSW patterns $-\mathrm{C}_{\mathrm{nil}}$ and $\mathrm{C}_{\min }$ (left) and $\mathrm{C}_{\max }$ (right)

of external influences prior to impact. This further reinforces a need to control variables as a measure of scientific rigour to allow accurate testing, hence to why the above testing conditions were set, to try and minimise the amount of variability beyond that which was to be examined.

\section{Conclusion}

$\mathrm{C}_{\max }$ significantly affected the damage sustained by a gelatine block shot by $7.62 \mathrm{~mm}$ or $5.45 \mathrm{~mm}$ projectiles raising the possibility of a more complicated surgical intervention being required for human casualties wearing such clothing combinations. $\mathrm{C}_{\min }$ did not affect the damage sustained by a gelatine block shot by $7.62 \mathrm{~mm}$ or $5.45 \mathrm{~mm}$ projectiles. Neither iteration of MTP clothing layers appeared to affect the propensity of bullet fragmentation, retention nor the path which was taken by the projectile after entering the gelatine block, though the latter was extremely difficult to quantify from the data collected.

Acknowledgements This work forms part of Surg Lt Cdr Tom Stevenson's PhD. Thanks are given to Cranfield university personnelClare Pratchett for the included artwork schematics and Michael Teagle,
David Miller and Alan Peare for their assistance with the range work; Defence Academy personnel-Lt Col Liz Nelson and WO2 Ian Morton for their assistance with range work; and MOD personnel-Mandy Hellyer and Stuart Maunder at HMS Nelson for the provision of the clothing samples used throughout testing.

Funding Information Funding was provided by the Royal Centre for Defence Medicine.

Open Access This article is distributed under the terms of the Creative Commons Attribution 4.0 International License (http:// creativecommons.org/licenses/by/4.0/), which permits unrestricted use, distribution, and reproduction in any medium, provided you give appropriate credit to the original author(s) and the source, provide a link to the Creative Commons license, and indicate if changes were made.

\section{References}

1. Stevenson T, Carr DJ, Penn-Barwell JG, Ringrose TJ, Stapley SA (2018) The burden of gunshot wounding of UK military personnel in Iraq and Afghanistan from 2003-14. Injury 49:1064-1069. https://doi.org/10.1016/j.injury.2018.03.028

2. Ogilvie H (1956) Lessons of the War that are already being forgotten. Guy's Hospital Gazette, October edn., London

3. Thoresby FP (1966) Cavitation: the wounding process of the high velocity missile - a review. J R Army Med Corps 112:89-99 
4. Carr DJ, Stevenson T, Mahoney P (2018) The use of gelatine in wound ballistics research. Int J Legal Med 132:1659-1664. https:// doi.org/10.1007/s00414-0181831-7

5. Stevenson WF (1898) Further Trial of Dum Dum Bullets, and of Bullets to R.L. Designs Nos. 9063 B and 9063 B

6. Callender GR, French RW (1935) Wound ballistics - studies in the mechanism of wound production by rifle bullets. Mil Surg 77(4): 177-201

7. Callender GR (1943) Wound ballistics - mechanism of production of wounds by small arms bullets and shell fragments. War Med 3(4):337-350

8. Newton Harvey E, McMillen JH (1946) An experimental study of shock waves resulting from the impact of high velocity missiles on animal tissues. J Exp Med 85:321-328

9. Krauss M (1957) Studies in wound ballistics: temporary cavity effects in soft tissues. Mil Med 121(4):221-231

10. Hopkinson DAW, Watts JC (1963) Studies in experimental missile injuries of skeletal muscle. Proc R Soc Med 56:461-468

11. Amato JJ, Billy LJ, Lawson NS, Rich NM (1974) High velocity missile injury: an experimental study of the retentive forces of tissue. Am J Surg 127:454-459

12. Berlin R, Gelin LE, Janzon B, Lewis DH, Rybeck B, Sandegård J, Seeman T (1976) Local effects of assault rifle bullets in live tissue. Part I. Acta Chir Scand Suppl 459:5-84

13. Fackler ML, Surinchak JS, Malinowski JA (1984) Wounding potential of the Russian AK-74 assault rifle. Trauma 24(3):263-266

14. Fackler ML, Breteau JP, Courbil LJ, Taxit R, Glas J, Fievet JP (1989) Open wound drainage versus wound excision in treating the modern assault rifle wound. Surgery 105(5):576-584

15. Peters CE, Sebourn CL (1996) Wound ballistics of unstable projectiles. Part II: temporary cavity formation and tissue damage. J Trauma Inj Infect Crit Care 40(3):S16-S21

16. Jussila J (2005) Measurement of kinetic energy dissipation with gelatine fissure formation with special reference to gelatine validation. Forensic Sci Int 150(1):53-62. https://doi.org/10.1016/j. forsciint.2004.06.038

17. Davis HJ (1897) Gunshot injuries in the late Greco-Turkish war, with remarks upon modern projectiles. Br Med J 2:1789-1793

18. Clasper JC, Hill PF, Watkins PE (2002) Contamination of ballistic fractures: an in vitro model. Injury 33(2):157-160

19. Eardley WG, Watts SA, Clasper JC (2013) Modelling for conflict: the legacy of ballistic research and current extremity in vivo modelling. J R Army Med Corps 159(2):73-83. https://doi.org/10.1136/ jramc-2013-000074

20. Wightman G, Wark K, Thomson J (2015) The interaction between clothing and air weapon pellets. Forensic Sci Int 246:6-16. https:// doi.org/10.1016/j.forsciint.2014.10.039

21. Giraudo C, Fais P, Pelletti G, Viero A, Miotto D, Boscolo-Berto R, Viel G, Montisci M, Cecchetto G, Ferrara SD (2016) Micro-CT features of intermediate gunshot wounds covered by textiles. Int $\mathrm{J}$ Legal Med 130(5):1257-1264. https://doi.org/10.1007/s00414016-1403-7

22. Kieser DC, Carr DJ, Leclair SCJ, Horsfall I, J-c T, Swain MV, Kieser JA (2013) Clothing increases the risk of indirect ballistic fractures. J Orthop Surg Res 8(42):1-6

23. Carr DJ, Kieser J, Mabbott A, Mott C, Champion S, Girvan E (2014) Damage to apparel layers and underlying tissue due to hand-gun bullets. Int J Legal Med 128(1):83-93. https://doi.org/ 10.1007/s00414-013-0856-1

24. Mabbott A, Carr DJ, Champion S, Malbon C (2016) Comparison of porcine thorax to gelatine blocks for wound ballistics studies. Int $\mathrm{J}$ Legal Med 130(5):1353-1362. https://doi.org/10.1007/s00414015-1309-9

25. Mahoney PF, Carr DJ, Miller D, Teagle M (2017) The effect of helmet materials and simulated bone and tissue layers on bullet behaviour in a gelatine model of overmatch penetrating head injury.
Int J Legal Med 131(6):1765-1776. https://doi.org/10.1007/ s00414-017-1665-8

26. Black AN, Burns BD, Zuckerman S (1941) An experimental study of the wounding mechanism of high velocity missles. Br Med J 2: $872-874$

27. Newton Harvey E, Butler EG (1944) Wound Ballistics

28. Calhoun GM (1955) Research, Development and Fabrication of Cartridge, Ball, Caliber .35 T-117-E-1. Remington Arms Company Inc.

29. Krauss M, Miller J (1960) Studies in Wound Ballistics Temporary Cavities and Permanent Tracts Produced by High-Velocity Projectiles in Gel

30. Thoresby FP (1964) Armalite Rifle (AR15) - Wound Ballistics Trials

31. Charters AC, Charters AC (1976) Wounding mechanisms of very high velocity projectiles. J Trauma 16(6):464-470

32. Cronin DS, Falzon C (2010) Characterization of $10 \%$ ballistic gelatin to evaluate temperature, aging and strain rate effects. Exp Mech 51(7):1197-1206. https://doi.org/10.1007/s11340-010-9438-z

33. Cronin DS (2011) Ballistic Gelatin Characterization and Constitutive Modeling. In: Proulx T (ed) Experimental and Applied Mechanics, Series 99. Springer, pp 51-55. https://doi. org/10.1007/978-1-4614-0216-9_7

34. Wilson L (1921) Dispersion of bullet energy in relation to wound effects. Mil Surg XLIX(3):241-251

35. Fackler ML, Surinchak JS, Malinowski JA (1984) Bullet fragmentation: a major cause of tissue disruption. J Trauma 24(1):35-39

36. Fackler ML, Malinowski JA (1985) The wound profile: a visual method for quantifying gunshot wound components. J Trauma 25(6):522-529

37. Fackler ML, Malinowski JA (1988) Ordnance gelatin for ballistic studies. Detrimental effect of excess heat used in gelatin preparation. Am J Forensic Med Pathol 9(3):218-219

38. Mabbott A, Carr DJ, Champion S, Malbon C, Tichler C (2013) Comparison of $10 \%$ gelatine, $20 \%$ gelatine and Perma-gel $^{\mathrm{TM}}$ for ballistic testing. In: 27 th international symposium on ballistics. pp 648-654

39. Mahoney PF, Carr DJ, Delaney RJ, Hunt N, Harrison S, Breeze J, Gibb I (2017) Does preliminary optimisation of an anatomically correct skull-brain model using simple simulants produce clinically realistic ballistic injury fracture patterns? Int J Legal Med 131(4): 1043-1053. https://doi.org/10.1007/s00414-017-1557-y

40. Ackley P (1978) Col. frank T. Chamberlin - gunshot wounds. In: Handbook for shooters and Reloaders, vol 2, 16th edn. Plazqa Publishing, Salt Lake City, pp 46-64

41. Humphrey C, Kumaratilake J (2016) Ballistics and anatomical modelling - a review. Legal Med 23:21-29. https://doi.org/10. 1016/j.legalmed.2016.09.002

42. Kneubuehl BP, Coupland RM, Rothschild MA, Thali MJ (2011) General wound ballistics. In: Wound ballistics: basics and applications, 3rd edn. Springer

43. Bowyer GW, Rossiter ND (1997) Management of gunshot wounds of the limbs. J Bone Joint Surg Br Vol 79(6):1031-1036

44. Mabbott A (2015) The overmatching of UK police body Armour. Cranfield University

45. Stevenson T, Carr DJ, Stapley SA (2017) The effect of clothing on gunshot wounds in gelatine: the naked truth. In: 30th international symposium on ballistics, Long Beach, California, USA

46. Morrow DS, Cupp JA, Broder JS (2016) Versatile, reusable, and inexpensive ultrasound phantom procedural trainers. J Ultrasound Med 35(4):831-841. https://doi.org/10.7863/ultra.15.04085

47. Ruschin M, Davidson SR, Phounsy W, Yoo TS, Chin L, Pignol JP, Ravi A, McCann C (2016) Technical note: multipurpose CT, ultrasound, and MRI breast phantom for use in radiotherapy and minimally invasive interventions. Med Phys 43(5):2508-2514. https:// doi.org/10.1118/1.4947124 
48. Lopes PA, Santaella GM, Lima CAS, Vasconcelos KF, Groppo FC (2018) Evaluation of soft tissues simulant materials in cone beam computed tomography. Dentomaxillofac Radiol 20180072. https:// doi.org/10.1259/dmfr.20180072

49. Janzon B, Seeman T (1985) Muscle devitalization in high-energy missile wounds, and its dependence on energy transfer. J Trauma 25(2):138-144

50. Sperrazza J, Kokinakis W (1968) Ballistic limits of tissue and clothing. Ann N Y Acad Sci 152:163-166

51. Tikka S, Cederberg A, Levanen J, Lotjonen V, Rokkanen P (1982) Local effects of three standard assault rifle projectiles in live tissue. Acta Chir Scand Suppl 508:61-77

52. Lewis EA, Breeze J, Malbon C, Carr DJ (2017) Personal Armour used by UK armed forces and UK police forces. In: Breeze J, Penn-Barwell JG, Keene D, O'Reilly D, Jeyanathan J, Mahoney PF (eds) Ballistic trauma: a practical guide, 4th edn. Springer International Publishing, pp 47-62. https://doi.org/10.1007/9783-319-61364-2_6

53. Gore SE, Laing RM, Wilson CA, Carr DJ, Niven BE (2006) Standardizing a pre-treatment cleaning procedure and effects of application on apparel fabrics. Text Res J 76(6):455-464. https:// doi.org/10.1177/0040517506063391

54. British Standards Institution (1998) BS EN 12127:1998, "determination of mass per unit area using small samples,". London

55. International Organization of Standardization (1996) ISO 5084: 1996, "textiles - determination of thickness of textiles and textile products,". Geneva

56. Penn-Barwell JG, Sargeant ID, Severe Lower Extremity Combat Trauma Study G (2016) Gun-shot injuries in UK military casualties - features associated with wound severity. Injury 47(5):1067-1071. https://doi.org/10.1016/j.injury.2016.02.004

57. Schroeder M, King B (2012) Surveying the battlefield: illicit arms in Afghanistan, Iraq and Somalia. In: McDonald G, LeBrun E, Berman EG, Krause K (eds) Small arms survey 2012. Cambridge University Press, New York, pp 313-355

58. Jussila J (2004) Preparing ballistic gelatine-review and proposal for a standard method. Forensic Sci Int 141(2-3):91-98. https://doi. org/10.1016/j.forsciint.2003.11.036

59. Mahoney PF (2018) Development of a synthetic bone and tissue model to simulate overmatch military ballistic head injury. Cranfield University 